\title{
Evaluation of a school-based Reproductive Health Education Program in rural South Western, Nigeria
}

\author{
Ademola J. Ajuwon, William R. Brieger
}

\begin{abstract}
This quasi-experimental study compared the relative efficacy of teacher instructions alone, peer education alone, and a combination of these two on reproductive health knowledge, attitude, perceived self-efficacy and sexual practices among secondary schools students in the Ibarapa district of Southwestern Nigeria. A baseline questionnaire was administered to a systematic sample of students in four schools that were randomized into four treatment arms: teacher instructions alone (E1), peer education alone (E2), combination of teacher instruction and peer education (E3), and control. The results were used to design the contents of the interventions, which were implemented for one academic session. A follow-up survey using the same sampling procedures as baseline was conducted to measure the outcome of the intervention. The control group had superior reproductive health knowledge at baseline. By follow-up survey however, all three intervention schools showed significant knowledge gains, while the control school students' mean score increased slightly. Increase in knowledge was greatest among E3 (+5.0 points), followed by E2 (+3.4), E1 (+1.4) and $\mathrm{C}(0.3)$. The intervention schools showed a significant positive shift in attitude towards use of contraceptives with mean increase of 0.6, 0.5, and 0.9 points in E1, E2 and E3 respectively. Scores that measured the students' perceived self-efficacy for safe sex increased significantly among E1 (from 10.8 to 11.8) and E3 (from 10.4 to 12.6). Reported condom use was significantly higher among E2 (from $16.7 \%$ to $62.8 \%$ ) ( $(\mathrm{p}<0.05)$ and E3 (from $22.8 \%$ to $53 \%$ ) ( $\mathrm{p}<0.05)$ compared to E1 $(28.6 \%$ to $47.4 \%)(\mathrm{p}>0.05)$ and control (from $25 \%$ to $45.8 \%)(\mathrm{p}>0.05)$. Overall, the students from E3 showed more improvement in knowledge, attitude and self-efficacy, than their counterparts from E2 and E3 and control. Multiple intervention strategies have greater potential of improving reproductive health of students. (Afr J Reprod Health 2007; 11[2]:47-59).
\end{abstract}

\section{RÉSUMÉ}

Evaluation d'un programme de l'éducation de la santé de reproduction basé sur l'école au sud-ouest rural, Nigéria Cette etude quasi-expérimental a comparé efficacité relative de seules les instructions de l'enseignant, l'éducation de pairs uniquement et une combinaison des deux sur la connaissance de la santé de reproduction, l'attitude, l'auto-efficacité perçue et les pratiques sexuelles parmi les étudiants de secondaire dans le district d’Ibarapa au sud ouest de Nigéria. Un questionnaire de ligne de base a été administré à un échantillon systématique d'étudiants dans quatre écoles réparties en quatre bras de traitement: seule les instructions de l'enseignement (E1), seule l'éducation des pairs (E2) la combination de l'instruction de l'enseignant et l'éducation des pairs (E3) et le témoin. On a dessiné le contenu des interventions à partir des résultats. Les interventions ont été mises en application pendant une année scolaire. Une enquête de suivi a été menée à l’aide des mêmes modalitiés de prélèvement que la ligne de base pour évaluer le résultat de l'intervention. Le groupe témoin avait une connaissance supérieure de la santé sur la ligne de base. A travers l'enqête de suivi, néanmoins, toutes les trois écoles d'intervention ont fait preuve d'acquis important, alors que la cote moyenne a augmenté légèrement. L'augmentation en connaissance était le plus chez le group E3 (+5, 0 points) suivi par E2 (3+, 4), $\mathrm{E} 1(+1,4)$ et $\mathrm{C}(0,3)$. Les écoles d'intervention ont fait preuve d'une modification positive d'attitude envers d'emploi des contraceptifs avec une croissance moyenne de 0,6, 0,5, et 0,9 points dans E1, E2 et E3 respectivement. Les cotes qui ont mesuré l'auto-efficacité perçue de la part des étudiants pour le rapport sexuel sans risque a augmenté de manière significative au sein des groupes E1(de 10,8 à 11,8 ) et E3(de 10,4 à 12, 6). Les cas signalés de l'emploi des préservatifs ont été plus élevés dans le groupe E2(de 16,7\% à $62,8 \%$ ) $(\mathrm{P}<0,05)$, E3(de 22,8\% à 53\%) $(\mathrm{P}<0,05)$ par rapport au groupe $\mathrm{E} 1(28,6 \%$ à 47, 4\%) $(\mathrm{P}<0,05)$ et le témoin $($ de $25 \%$ à $45,8 \%)(\mathrm{P}<$ $0,05)$. Dans l'ensemble, les étudiants du groupe E3 ont fait preuve d'une méilleure amélioration en ce qui concerne la connaissance, l'attitude et l'auto-efficacité que leurs homologues des groupe E2, E3 et le groupe témion. Des stratégies d'interventions multiples ont plus de potentiel d'améliorer la santé de reproduction des étudiants. (Rev Afr Santé Reprod 2007; 11[2]:47-59).

KEY WORDS:

Ademola J. Ajuwon, MPH, PhD' William R. Brieger, MPH, CHES, DrPH

${ }^{1}$ Department of Health Promotion and Education, College of Medicine, University of Ibadan, Nigeria ${ }^{2}$ Department of International Health, Johns Hopkins School of Public Health, Baltimore, Maryland, USA

Correspondence: Dr. Ademola J. Ajuwon, Department of Health Promotion and Education, College of Medicine, University of Ibadan, Nigeria Email:ajajuwon@yahoo.com 


\section{Introduction}

Developing strategies to address the reproductive health needs and concerns of the adolescents in Nigeria poses a major public health challenge. One of the factors contributing to this challenge is the sheer size of the adolescent population in the country. ${ }^{1}$ Adolescents (i.e. persons aged 1019 years) account for a significant proportion of Nigeria's population of 140 million. ${ }^{2}$ The second challenge is that a significant proportion of the Nigerian adolescents engage in risky practices including unprotected sex with multiple partners ${ }^{3-}$

5 For example, Jinadu and Odesanmi ${ }^{3}$ studied male adolescents aged 15-19 years in southwestern Nigeria and found that $76 \%$ of the secondary school youths had been sexually active within the past 12 months, $5 \%$ with prostitutes and $56 \%$ with more than one partner, but that only $8 \%$ had used a condom during that year. Consequently, adolescents and other young adults account for a high proportion of sexually transmitted diseases (STD) including human immunodeficiency virus (HIV) in the country. Ekwezor and colleagues, ${ }^{6}$ in a study of patients attending an STD clinic in Ibadan, found that the peak prevalence $(65 \%)$ of HIV infection was among those aged 21-30 years, most of who were probably infected during adolescence. In 1999, persons aged less than 24 years accounted for $10 \%$ of all HIV infections compared to $5.4 \%$ for adults.

Individuals researchers ${ }^{8,9}$ and non-governmental youth serving organizations $(\mathrm{YSO})^{10}$ have responded to these challenges by implementing several reproductive health promotion programs to increase adolescents' knowledge of reproduction, HIV/AIDS and influence risky sexual behaviors targeting in-school and out-of school adolescents. ${ }^{5,11}$ Despite these efforts, the reproductive health needs of the majority of adolescents remain neglected because these programs have been implemented on a small scale, are of limited duration, and are concentrated in urban areas, even though the majority of adolescents live in rural communities.
Although schools are important potential sources of reproductive health education for adolescents, these institutions have not reached their full potential because the Nigerian government has not yet formally introduced reproductive health education into existing curricula. As a result, all school-based reproductive health programs have utilized an extra-curricular approach including peer education in which trained students inform, counsel, and distribute non-prescriptive contraceptives to their colleagues ${ }^{9,10,12}$ Other school-based programs have trained teachers who deliver reproductive health education including HIV/AIDS prevention as part of extracurricula activities in schools. ${ }^{8}$

Studies have demonstrated the value of peer education alone $e^{9,10,12}$ and teachers' instruction alone on the reproductive health of adolescents but few have compared the relative effects of these two interventions on the reproductive health knowledge and practices of adolescent students. Yet, such comparison is important because it will enable researchers make appropriate recommendations on the most effective intervention strategy to address the reproductive health needs of students. This study presents the results of a research that compares the relative effects of peer education, teacher instructions and a combination of the two on the reproductive health knowledge, attitudes, self-efficacy and sexual practices of secondary school students in rural Oyo State, Nigeria.

\section{METHODS}

\section{The Setting}

The study was conducted in Ibarapa, a district with an approximate population of 195, 897 in rural southwestern Nigeria. ${ }^{13}$ Ibarapa consists of seven main towns namely Ayete, Eruwa, Idere, Igangan, Igbo-ora, Lanlate and Tapa. In Ibarapa, subsistence farming is the mainstay of the local economy while Yoruba are the dominant ethnic group. Each of the seven major towns in Ibarapa

African Journal of Reproductive Health Vol. 11 No.2 August 2007 
has health facilities that provide clients with some reproductive health services, including contraceptives. However, adolescents under utilize these facilities because they are designed primarily to meet the needs of adults and suffer chronic shortage of supplies. Although the traditional Yoruba value discourages pre-marital sexual activity, Ibarapa has experienced marked social change in recent years due to the continuing decline of traditional, religious norms, and economic hardship. Consequently, premarital sexual activity is now common in this area. ${ }^{14}$ Like other Yoruba communities, the Ibarapa community has a double standard of sexual morality based on gender. Women are expected to be absolutely faithful to their husbands while it is acceptable for men to have multiple partners. ${ }^{15}$

\section{Sampling}

The study was quasi-experimental in design with four secondary schools participating in it. As part of planning for the baseline survey, all the secondary schools in the district were enumerated and it was found that there were 24 schools in the area at the time of the study. A break-down of the schools by location showed that 9 were located in Igbo-ora, 5 in Eruwa, while Lanlate, Ayete, Igangan, Idere and Tapa had 2 each. The schools fell into three categories based on their years of establishment. One category was first generation schools which were established in the 1960s. There were one each of this category in Igbo-ora and Eruwa. The second category consisted of schools established in the early 1980s by the civilian state government at a time when free education was being offered at secondary schools. There were 20 schools in this category. The third category consisted of schools established in the early 1990s, and as with the older schools, there were only two of these. Since there were only four schools in the two extreme categories, it was decided to draw from the 20 schools that were comparable with respect to the fact that they were established by the civilian administration at the time, that they were under the same management and that they were co-educational. None of these 20 schools had boarding facilities at the time of the study.

The investigators set four as the number of schools to participate in each arm of the treatments (teacher instruction only, peer education only, combination of the two and a control) to be tested in the study due to funding constraints. The next step was to select one school each from four towns that were reasonably far apart from each other to avoid contamination which will occur if the schools are proximal to each other. Consequently, the schools selected by balloting were based in Igbo-ora, Eruwa, Lanlate and Igangan. The distance between each of these towns is approximately 10-25 kilometers, limiting the opportunity of social interactions among students of the schools. In addition, the policy of the Oyo state government regarding school enrolment is that students should attend schools located not more than two kilometres from their place of residence. The students' population of these schools range from 450-1009 in 1997 when the baseline survey was conducted.

Based on sample size calculations using knowledge of reproductive health from a previous similar study, i.e. the West Africa Youth Initiative ${ }^{16}$, we calculated the sample size to be a minimum of 230 per arm of treatment. The first step in the process of selection of the students surveyed was an enumeration of all arms (streams) in the junior and senior classes in the four schools selected for the study. In Nigeria, the secondary school system is divided into two categories; junior and senior classes with each having three levels (1-3). Secondly, one arm was randomly selected by balloting from each level making a total 6 per school and overall total of 24. Thirdly, a systematic technique based on gender was used to select a sample of 42 students from each class using the register. A similar procedure was adopted during the follow-up survey. 
Using this approach, the samples selected in Eruwa, Igangan, Igbo-ora and Lanlate at baseline were 259, 257, 243 and 246 respectively. The corresponding figures for follow-up were 260, 258, 243 and 268 respectively. The schools were randomized into four treatment arms as follow teacher instructions alone (E1) (Eruwa), peer education alone (E2) (Igangan), combination of teacher instruction and peer education (E3) (Igboor), and control (Lanlate) (See Figure One for details).

\section{Measures}

A 54-item questionnaire was developed and used for data collection. The questionnaire documented demographic characteristics, reproductive health knowledge, discussions of reproductive health issues, attitude towards use of contraceptives, perceived self-efficacy (PSE) for safe sex, and sexual practices. This instrument built upon previously tested questionnaires from other surveys of reproductive health among adolescents in Nigeria. ${ }^{10,12}$ The knowledge questions focused on timing of conception, methods of contraceptives, the routes of infection and prevention of STD/HIV/AIDS. With respect to reproductive health discussion, students were asked whether they had talked about adolescent growth and development, pregnancy and STD with anyone. The students' attitudes to use of contraceptives were gauged by requesting them to "agree", "disagree" or be "undecided" to five statements on use of contraceptives. Students PSE was assessed by requesting them to determine their perceived level of confidence to request for, buy, or use a condom. Finally, sexual practices focused on whether or not students had ever had coitus, if it occurred in three months preceding the survey, number of partners and use of condoms at last sexual encounter. A draft of the questionnaire was pre-tested among 20 students from one of the schools in the district to confirm clarity and comprehension.

\section{Procedures for Data Collection}

The questionnaires were self-completed by the students during school hours under the supervision of trained research assistants (RA). Selected students were assembled into a classroom where RA provided instructions on how to complete the questionnaires. Prior to completing the questionnaire the RA explained the purpose of the study and that the students' participation in it was voluntary. The assistants collected the questionnaires immediately after the students completed them. The placement of students into a class to complete the questionnaire was adopted for logistic reasons. Since not all students in a selected class were involved in completing the questionnaire the researchers considered it most appropriate that selected students should leave the class while those left behind could continue with their lessons. This procedure ensured that the administration of the questionnaire did not disrupt the schools activities for the entire day. This procedure did not affect confidentiality of the interviews because the questionnaire was anonymous.

\section{The Intervention}

\section{Design and Set-Up}

The baseline data were used to design the contents of the interventions, which were implemented for one academic session (approximately nine months) (See Figure 1). As parts of planning for the intervention, students were requested to nominate teachers and students who they prefer as sources of reproductive health information and services. In E1 students nominated 8 teachers, two were nominated from $\mathrm{E} 2$ and 7 from E3. These teachers were trained for five days on adolescent sexuality, communication, human reproduction, pregnancy prevention, STD/HIV/AIDS, condom promotion and distribution, drug abuse, malaria, guinea worm. Relevant training methods including role-play, group work, discussions, demonstrations and film

African Journal of Reproductive Health Vol. 11 No.2 August 2007 
shows were used during training. Upon completion of the training, teachers were provided with course materials, educational materials, condoms, forms to document their activities, and assigned to various classes based on existing teaching arrangements. However, teachers from E2 where peer education strategy alone was implemented were not assigned to any class. Instead, they served as supervisors for the peer educators in that school.

A set but similar five-day training programs were organized for each set of the of 22 peer educators (PE) in E2 and E3 who were also nominated by their colleagues. In addition, the trained PE were provided with condoms, educational materials and evaluation forms. The form contained information about the nature of intervention carried out and describes the gender of the students reached with intervention.

\section{Monitoring and supervision of intervention Activities}

Since the project was based on use of extracurricular strategy, teachers and students were encouraged to use innovative approaches to address the reproductive health needs and concerns of students' population in each of the intervention schools. Eight rounds of monthly meetings were held with each group of teachers and peer educators in the three intervention schools to provide them with supportive supervision. During meetings, investigators reviewed the activities carried out by $\mathrm{PE}$ and teachers in previous months and discuss their future plans. In addition, PE and teachers' needs and concerns such as request for additional materials were addressed during the meetings. The $\mathrm{PE}$ and teachers implemented the intervention in each school for one academic session starting in January 1997 through March 1998. The effects of these interventions were measured by conducting a follow-up survey using the same methodology used for the baseline survey.

The intervention activities accomplished in each of the three experimental schools are summarized in Table 3. In E1, teachers provided approximately 68 hours of instructions on several aspects of reproductive health integrated into teachings and made rotational presentations to the entire student's population on STD/HIV/ AIDS prevention. In E2, PE counseled 500 students, distributed 185 condoms and 570 educational materials. In E3, PE counseled 551 students, organized on drama presentation and distributed 54 condoms. The teachers in that school provided 200 hours of instructions integrated into their teaching subjects.

\section{Data Analysis}

The questionnaires were verified for completeness in the field. Open-ended questions were coded and the data were entered into a computer. The data analysis was done with EPI INFO software developed by the Centers for Disease Control and Prevention of the USA. Knowledge variable was summarized by assigning one point to each

\section{Figure 1: Description of the design of the project}

\begin{tabular}{|l|l|l|l|}
\hline Groups & \multicolumn{2}{|c|}{ Measurements } & Follow-up \\
\hline & Baseline & Interventions & $\mathrm{X}$ \\
\hline Experimental group one $\left(\mathrm{E}^{1)}\right.$ & $\mathrm{X}$ & $\mathrm{X}$ (Teacher instruction only) & $\mathrm{X}$ \\
\hline Experimental group two $\left(\mathrm{E}^{2)}\right.$ & $\mathrm{X}$ & $\mathrm{X}$ (peer education only) & $\mathrm{X}$ \\
\hline Experimental group three $\left(\mathrm{E}^{3)}\right.$ & $\mathrm{X}$ & $\mathrm{X}$ (Teacher instruction \& peer education) & $\mathrm{X}$ \\
\hline Control group $(\mathrm{C})$ & $\mathrm{X}$ & 0 & \\
\hline
\end{tabular}

African Journal of Reproductive Health Vol. 11 No.2 August, 2007 
Table 1: Summary of educational activities implemented by teachers and peer educators in intervention schools

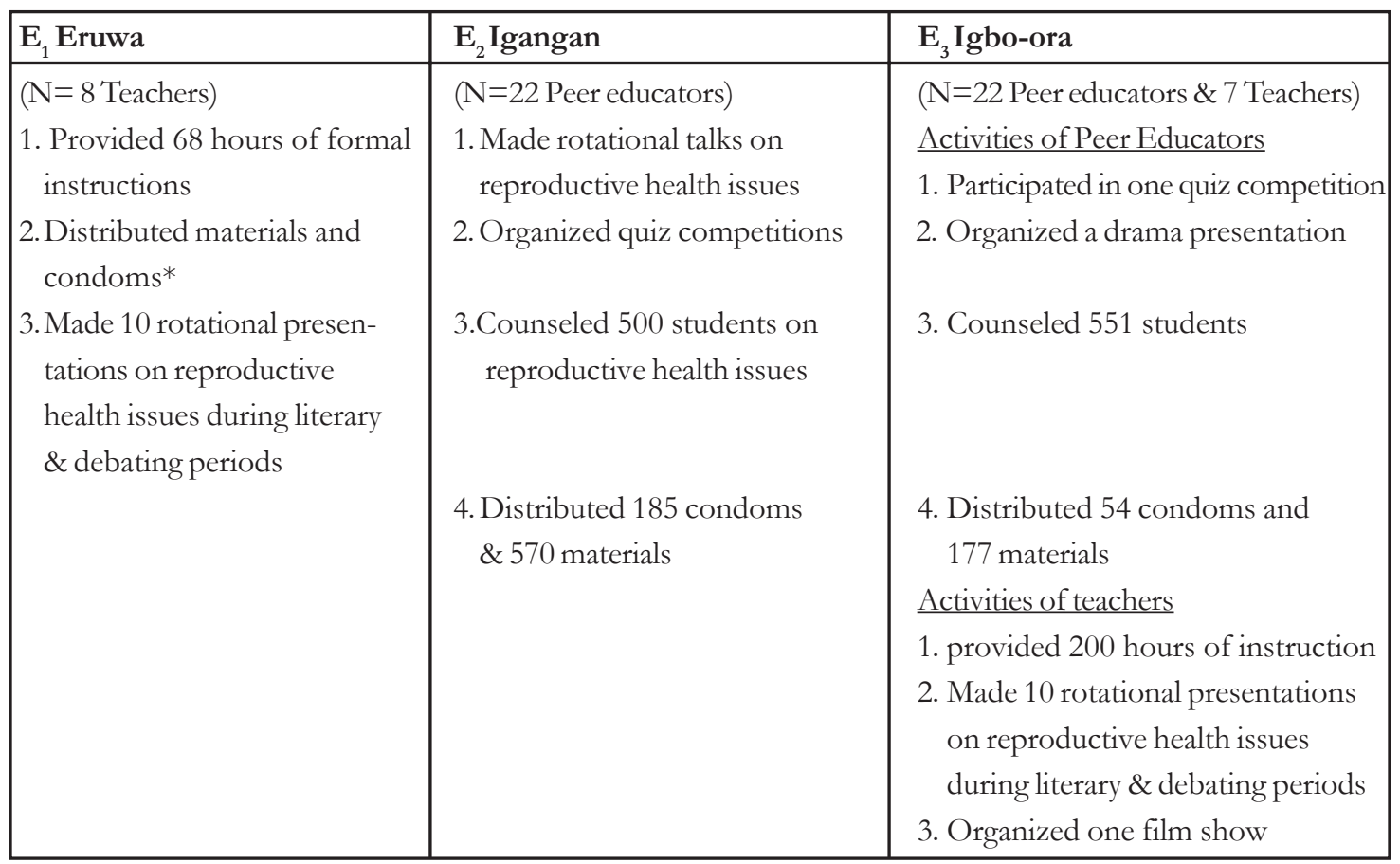

-The teachers did not document the number of materials distributed

correct answer provided by student leading to the development of a 34-point knowledge score. Data on attitude was summarized by assigning three points to each of the five statements leading to a 15-point attitude score; three points was also assigned to the six statements on PSE leading to development of an 18 points PSE score.

\section{Results}

\section{Baseline Characteristics of the students}

Approximately equal number of males and females were surveyed (Table Two). Their ages ranged from 10 to 25 years. With a mean age of 16.05 years, students from E3 were slightly older than their counterparts from E1 (15.24), E2 (15.94) and control (15.66) $(\mathrm{p}<0.05)$. Christianity and Islam were the dominant religions practiced by the students. With respect to marital status, almost all the students had never been married before. The proportion of single students ranged from $94.2 \%$ in $\mathrm{E} 1,96.1 \%$ in $\mathrm{E} 2,90 \%$ in $\mathrm{E} 3$ to $(99.2 \%)$ in control $(\mathrm{p}<0.05)$.

\section{Knowledge, Attitude, Self-efficacy and sexual practices}

Table Three presents the baseline characteristics of students concerning reproductive health knowledge, discussion, attitude, PSE and sexual practices. The mean knowledge scores obtained by the students ranged from 2.324 in E1 to 3.069 in control out of 34 points $(\mathrm{p}<0.05)$. Students from E2 reported the highest level of previous discussion of reproductive health issues having spoken to a total of 182 persons with a mean number of 0.7 ( $p>0.05)$. With a mean score of 9.9 (out of 15), students from control showed more positive attitude towards use of contraceptives than their counterparts from other schools

\footnotetext{
African Journal of Reproductive Health Vol. 11 No.2 August 2007
} 
Table 2: Demographic characteristics of secondary school students in Ibarapa district

\begin{tabular}{|c|c|c|c|c|c|c|}
\hline Variable & $\begin{array}{l}\mathrm{E}^{1} \\
\text { Teacher } \\
\text { Instruct. } \\
\text { only }\end{array}$ & $\begin{array}{l}E^{2} \\
\text { Peer } \\
\text { educat. } \\
\text { Only }\end{array}$ & $\begin{array}{l}\mathrm{E}^{3} \\
\text { Combined } \\
\text { Intervention }\end{array}$ & Control & Statistics & Pvalue \\
\hline $\begin{array}{l}\text { Sex } \\
\text { Male } \\
\text { Female }\end{array}$ & $\begin{array}{l}127(49 \%) \\
132(51 \%)\end{array}$ & $\begin{array}{l}129(50.2 \%) \\
128(49,8 \%)\end{array}$ & $\begin{array}{l}126(50.8 \%) \\
122(49.2 \%)\end{array}$ & $\begin{array}{l}118(48 \%) \\
128(49.2 \%)\end{array}$ & $\mathrm{X} 2=0.47$ & 0.92 \\
\hline $\begin{array}{l}\text { Class } \\
\text { Junior } \\
\text { Senior }\end{array}$ & $\begin{array}{l}136(52.5 \%) \\
123(47.5 \%)\end{array}$ & $\begin{array}{l}139(54.3 \%) \\
117(45.7 \%)\end{array}$ & $\begin{array}{l}131(52.8 \%) \\
117(47.2 \%)\end{array}$ & $\begin{array}{l}126(51.2 \%) \\
120(48.8 \%)\end{array}$ & $\mathrm{X} 2=15.90$ & 0.39 \\
\hline $\begin{array}{l}\text { Age } \\
\text { Mean }\end{array}$ & 15.24 & 15.94 & 16.05 & 15.66 & Fvalue $=6.228$ & 0.034 \\
\hline $\begin{array}{c}\text { Religion } \\
\text { Christian } \\
\text { Moslem }\end{array}$ & $\begin{array}{l}207(80.2 \%) \\
48(18.8)\end{array}$ & $\begin{array}{l}159(61.9 \%) \\
95(37.0 \%)^{*}\end{array}$ & $\begin{array}{l}75(56.1 \%) \\
162(66 \%)^{*}\end{array}$ & $\begin{array}{l}138(56.1 \%) \\
107(43.5 \%)\end{array}$ & $X 2=135.76$ & 0.0000 \\
\hline $\begin{array}{l}\text { Status } \\
\text { Single } \\
\text { Married } \\
\text { N }\end{array}$ & $\begin{array}{l}244(94.2 \%) \\
15(5.8 \%) \\
259\end{array}$ & $\begin{array}{l}247(96.1 \%) \\
10(3.9 \%) \\
257\end{array}$ & $\begin{array}{l}217(90 \%) \\
24(10 \%) \\
248\end{array}$ & $\begin{array}{l}243(99.2 \%) \\
2(0.8 \%) \\
246\end{array}$ & $\mathrm{X} 2=22.12$ & 0.0006 \\
\hline
\end{tabular}

$(\mathrm{p}<0.05)$. Students from E2 had significantly higher PSE for safe sex than those from E1 (10.8), E3 (10.4), and control (11.1) $(\mathrm{p}<0.05)$.

Concerning sexual practices, overall less than $10 \%$ of the students reported ever having sexual intercourse. The proportion with sexual experience ranged from $8.8 \%$ in $\mathrm{E} 3,6.9 \%$ in $\mathrm{E} 1$, $3.8 \%$ in $\mathrm{E} 2$ to $3.2 \%$ in control $(\mathrm{p}<0.05)$. On the other hand, students from E1 had more partners (6.0) than those from E3 (2.3), E2 (1.0) and control (1.3) $(p<0.05)$. Generally, many of those with sexual experience did not use a condom during their last sexual encounter. The proportion of condom users ranged from $27.8 \%$ in E1, 25\% in control, $22.7 \%$ in $\mathrm{E} 3$ and $20 \%$ to $\mathrm{E} 2$ ( $\mathrm{p}>0.05)$.

\section{The Effects of the Intervention}

The effects of the intervention are summarized on Table 4. Overall, the intervention schools showed significantly higher knowledge scores than the control school at follow-up $(\mathrm{p}<0.05)$. Knowledge gained in the intervention schools ranged from 1.4 points in E1, 3.4 in $\mathrm{E} 2$ to 4.9 in E3. With a mean of 1.6 persons, students from E3 held significantly more discussions with other persons than their counterparts from E2 (1.5), E1 (1.1) and control (0.7) $(\mathrm{p}<0.05)$. Overall, the three experimental schools recorded a significant increase at follow-up over baseline.

Concerning attitude toward contraceptives, the two schools that had PE had the highest (most favorable) mean score, 10.2 for E3 and 10.0 for E2. All intervention schools also showed significant positive change on this variable when compared with their baseline and follow-up scores. The mean net increase is 0.6 for E1, 0.5 for E2, 0.9 for E3 while the control showed a significant decline of 0.9 . 
54 African Journal of Reproductive Health

Table 3: Baseline Reproductive health knowledge, attitude, self efficacy and sexual practices of students in Ibarapa

\begin{tabular}{|c|c|c|c|c|c|c|}
\hline Variable & $\begin{array}{l}\text { E1 } \\
\text { Teacher } \\
\text { Instruct }\end{array}$ & $\begin{array}{l}\text { E2 } \\
\text { Peer } \\
\text { education }\end{array}$ & $\begin{array}{l}\text { E3 } \\
\text { Mixed } \\
\text { interv. }\end{array}$ & $\mathbf{C}$ & Statistic & Pvalue \\
\hline $\begin{array}{l}\text { Mean } \\
\text { Knowledge scores of } \\
\text { reproductive health }\end{array}$ & 2.324 & 2.350 & 2.032 & 3.069 & Fvalue 7.224 & 0.034 \\
\hline $\begin{array}{l}\text { Discussion of reproductive } \\
\text { health } \\
\text { No of persons } \\
\text { Mean }\end{array}$ & $\begin{array}{l}156 \\
0.6\end{array}$ & $\begin{array}{l}182 \\
0.7\end{array}$ & $\begin{array}{l}143 \\
0.6\end{array}$ & $\begin{array}{l}144 \\
0.6\end{array}$ & $\mathrm{~F}=0.621$ & 0.601527 \\
\hline $\begin{array}{l}\text { Mean scores for attitudes } \\
\text { towards contraceptives }\end{array}$ & 9.397 & 9.624 & 9.414 & 9.978 & $\mathrm{~F}=4.223$ & 0.005 \\
\hline $\begin{array}{l}\text { Perceived self efficacy for } \\
\text { safe sex }\end{array}$ & 10.786 & 11.380 & 10.375 & 11.101 & $\mathrm{~F}=2.577$ & 0.03 \\
\hline Proportion that ever had sex & $18(6.9 \%)$ & $10(6.9 \%)$ & $22(8.8 \%)$ & $8(3.3 \%)$ & $X 2=9.63$ & 0.022 \\
\hline Condom users & $5(27.8 \%)$ & $2(20 \%)$ & $5(77.3 \%)$ & $2(25 \%)$ & $\mathrm{X} 2=0.25$ & 0.96 \\
\hline $\mathrm{N}$ & 259 & 257 & 248 & 246 & & \\
\hline
\end{tabular}

The experimental schools recorded significant gains $(p<0.05)$ over control at follow-up on PSE skills. Students from E3 recorded the highest improvement on this variable (12.6), followed by those in E1 (11.8), E2 (11.6) and control (10.9). PSE scores rose significantly in E1 from 10.7 at baseline to 11.7 at follow-up, from 10.3 to 12.6 in E3. The increase of 11.3 to 11.5 in E2 was not significant $(\mathrm{p}>0.05)$ and the decline from 11.1 to 10.9 in control was also not significant $(\mathrm{p}>0.05)$.

The proportion of students who reported sexual experience in the three months preceding the survey were $7.3 \%$ in E1, $16.7 \%$ in E2, $13.2 \%$ in $\mathrm{E} 3$ and $9.0 \%$ in control $(\mathrm{p}<0.05)$. Looking at the rate of sexual activities over time, students from E2 recorded a significant increase $(4.7 \%$ to16.7\%) in sexual activity, while in E3; there was slight but not significant increase ( $9.4 \%$ to $13.2 \%)$. A significant increase was also found among students from control $(3.3 \%$ to $9.0 \%)(\mathrm{p}<0.05)$. However, a general decline occurred in the reported mean number of partners over time.
The reduction ranged from 6.0 to 2.1 in E1, 2.3 to1.9 in E3; however number of partners increased from 1.0 to 1.5 in E2. A similar situation occurred in control where number of partners rose from 1.3 partners to 2.2 but these were not significant $(\mathrm{p}>0.05)$.

There was a significant increase in reported condom use in E3 (i.e. from $20.8 \%$ to $53.1 \%$ ). Students from control also showed an increase in condom use over time, but like the students in E1, the proportion did not pass 50\% at either point in time (from $25.0 \%$ to $45.8 \%$ ) and was not significant. In comparing the schools at follow-up, the highest proportion of reported condom use occurred in E2 (62.8\%), and the lowest at control $(45.8 \%)(\mathrm{p}>0.05)$.

\section{Testing the Relative Effects of Interventions}

The intervention had statistically positive impact on knowledge, discussion about reproductive health, attitudes toward contraceptives and self- 
Table 4: Follow-up reproductive health knowledge, attitude, self efficacy and sexual practices of students in Ibarapa

\begin{tabular}{|l|l|l|l|l|l|c|}
\hline Variable & E1 & E2 & E3 & C & Statistic & P value \\
\hline $\begin{array}{l}\text { Mean } \\
\text { Knowledge scores of } \\
\text { reproductive health }\end{array}$ & 3.769 & 5.721 & 7.00 & 3.410 & $\mathrm{~F}=64.710$ & 0.000 \\
\hline $\begin{array}{l}\text { Discussion of reproductive } \\
\text { health } \\
\begin{array}{l}\text { No of persons } \\
\text { Mean }\end{array}\end{array}$ & 266 & 382 & 382 \\
1.1 & 1.4 & 1.5 & $\begin{array}{l}185 \\
0.6\end{array}$ & $\mathrm{~F}=14.0888$ & 0.0000 \\
\hline $\begin{array}{l}\text { Mean scores for attitudes } \\
\text { towards contraceptives }\end{array}$ & 9.667 & 10.107 & 10.277 & 9.527 & $\mathrm{~F}=5.315$ & 0.001 \\
\hline $\begin{array}{l}\text { Mean scores for perceived } \\
\text { self efficacy for safe sex }\end{array}$ & 11.761 & 11.550 & 12.620 & 10.927 & $\mathrm{~F}=7.229$ & 0.0086 \\
\hline $\begin{array}{l}\text { Proportion that had } \\
\text { ever had sex }\end{array}$ & $19(7.3 \%)$ & $43(16.7 \%)$ & $32(13.2 \%)$ & $24(9.0 \%)$ & $\mathrm{X} 2=13.66$ & 0.0034 \\
\hline $\begin{array}{l}\text { Proportion who used } \\
\text { condom last sex act }\end{array}$ & $9(47.4 \%)$ & $27(62.8 \%)$ & $17(53.1 \%)$ & $11(45.8 \%)$ & $\mathrm{X} 2=2.33$ & 0.51 \\
\hline Mean number of partners & 2.1 & 1.5 & 1.9 & 2.2 & $\mathrm{X} 2=0.902$ & 0.0000 \\
\hline
\end{tabular}

Table 5: Comparison of Follow-up Knowledge Scores on a School-by-School Basis

\begin{tabular}{llllll}
\hline SCHOOL & & Mixed & Instruction & Peers & Control \\
\hline & mean & 7.00 & 3.77 & 5.72 & 3.41 \\
& st dev & 4.10 & 3.09 & 3.16 & 2.97 \\
\hline Mixed & t value & - & 10.014 & 3.924 & 11.399 \\
& p value & & 0.000000 & 0.000099 & 0.000000 \\
\hline Instruction & t value & - & - & 7.111 & 1.360 \\
& p value & & & 0.000000 & 0.174408 \\
\hline Peer & t value & - & - & - & 8.648 \\
Education & p value & & & & 0.000000 \\
\hline
\end{tabular}

efficacy for safe sex, but not on sexual practices. Therefore, further analysis was done on each of these variables on a school-by-school basis to determine the relative effects of the interventions. The mixed intervention led to superior gains (7) in knowledge than peer education (5.72) and teacher instructions (3.77) and control (3.41) $(\mathrm{p}<0.05)$ (Table 5). On the other hand, peer education was superior to teacher instruction and control $(\mathrm{p}<0.05)$.

African Journal of Reproductive Health Vol. 11 No.2 August, 2007
Concerning discussion of reproductive health issues, mixed intervention was not better than peer education; however each of these interventions produced better results than instructions and control but instructions was not better than control (Table 6). Similarly the mixed intervention produced comparable effects on attitudes towards contraceptives as peer education but was significantly better than either the instructional or the control groups. The peer education only group 
scored better than both the instructional and control groups, but the difference was of borderline significance compared to the instructional group and of actual statistical when compared with the control group (Table 7). Finally, the mixed intervention produced significantly higher mean PSE (12.6) than any other intervention or the control groups. The peer education group score (11.6) was slightly, but not significantly lower than the instructional group (11.8). While the difference between peer education and control (10.9) scores was of borderline significance, the instructional group had a clearly significantly higher mean score than the control group (Table 8). In summary, mixed intervention have greater positive effects on reproductive health knowledge, discussions, attitudes and PSE for safe sex among the students surveyed.

\section{Discussion}

The intervention had a positive impact on students' knowledge of reproductive health. Whereas at baseline, students from the control school were the most knowledgeable about reproductive health the situation was reversed at follow-up; with students in the mixed intervention school having the highest gains in knowledge. This finding agrees with the results of previous studies of secondary school students that knowledge can increase after any educational intervention." 10 This improvement is not only encouraging but also desirable because acquisition of knowledge is usually the first stage in the process of changes in behavior. However, knowledge alone is often not sufficient in itself to produce change in sexual behavior in most people. $^{17}$

Table 6: Comparison of Follow-up Scores for Talking with Someone about Reproductive Health Issues on a School-by-School Basis

\begin{tabular}{llllll}
\hline SCHOOL & & Mixed & Instruction & peers & Control \\
\hline & mean & 1.572 & 1.100 & 1.477 & 0.690 \\
& st dev & 2.008 & 1.622 & 1.847 & 1.387 \\
\hline Mixed & t value & - & 2.909 & 0.533 & 5.820 \\
& p value & & 0.004 & 0.58 & 0.000000 \\
\hline Instructional & t value & - & - & 2.467 & 3.123 \\
& p value & & & 0.014 & 0.002 \\
\hline Peer & t value & - & - & - & 5.537 \\
Education & p value & & & & 0.000000 \\
\hline
\end{tabular}

Table 7: Comparison of Follow-up Contraceptive Attitude Scores on a School-by-School Basis

\begin{tabular}{llllll}
\hline SCHOOL & & Mixed & Instructions & peers & control \\
\hline & mean & 10.227 & 9.667 & 10.107 & 9.527 \\
& st dev & 2.175 & 2.042 & 2.343 & 1.847 \\
\hline Mixed & t value & - & 2.837 & 0.991 & 3.731 \\
& p value & & 0.005 & 0.32 & 0.0002 \\
\hline Instructional & t value & - & - & 1.718 & 0.774 \\
& p value & & & 0.08 & 0.44 \\
Peer & t value & - & - & - & 2.518 \\
education & p value & & & & 0.01
\end{tabular}


Table 8: Comparison of Follow-up Perceived Self-Efficacy Scores on a School-by-School Basis

\begin{tabular}{llllll}
\hline SCHOOL & & Mixed & Instruction & peers & control \\
\hline & mean & 10.342 & 10.514 & 10.752 & 10.159 \\
& st dev & 5.570 & 4.574 & 4.129 & 4.087 \\
\hline Mixed & t value & - & 0.371 & 0.922 & 0.414 \\
& p value & & 0.712 & 0.357 & 0.679 \\
\hline Instructional & t value & - & - & 0.621 & 0.933 \\
& p value & & & 0.535 & 0.351 \\
\hline Peer & t value & - & - & - & 1.648 \\
Education & p value & & & & 0.099 \\
\hline
\end{tabular}

Another positive effect of the interventions is seen in the discussion of reproductive health issues. This is encouraging given the fact that the traditional social context in Ibarapa does not favor open discussion of reproductive health issues. This finding, however different from results of one survey that suggests that a coeducational school setting tends to inhibit free discussion of reproductive health matters, while single sex schools creates a freer environment for such discussions. ${ }^{18}$ By placing the responsibility of reproductive health education in the hands of teachers and students, the programs in the intervention schools created a social environment that favored open discussion of reproductive health issues.

Peer education alone and mixed intervention had a significant impact on the students' attitude towards contraception. This agrees with results from previous studies that peer-led intervention can have a positive influence on the attitude of secondary school students towards use of contraceptives $^{10,16}$ and on the attitude of out-ofschool youths towards practicing personal preventive behaviors and seriousness of AIDS. ${ }^{19}$ Similar results were found from a research in a secondary school in Igbo-ora where peer education positively influenced the attitude of students towards use of psychoactive substances including alcohol and cigarette. ${ }^{20}$ This change in attitude is encouraging since attitude is a predictor of intentions to undertake any behavior. ${ }^{21}$

African Journal of Reproductive Health Vol. 11 No.2 August, 2007
However, teachers' instruction did not have any effect on the attitude of the students. It is also possible that the teachers from this school were not convinced about the need for students to use contraceptives. The implication is that formal instruction must be combined with more interactive approaches such as peer education to bring about positive change in attitude towards use of contraceptives.

A reduction occurred over time in the reported number of partners among students from the intervention schools while students from the control school reported an increase in the number of sexual partners. The rate of the reduction in the number of partners was however more dramatic in E1 (from 6.0 to 2.9). This compares with the study by Osowole ${ }^{9}$ who found a decrease in the number of sexual partners after a sample of secondary school students in Ibadan were exposed to peer education. This is encouraging because reduction in the number of sexual partners lowers the risk of exposure to STD including HIV. ${ }^{22}$ However, this data need to be interpreted with caution because the students may have over estimated their number of partners at baseline. But having participated in the program and become familiar with the questionnaire, some students may have felt more comfortable and therefore provided more accurate information at follow-up. Although there was an increase in sexual activities in Igangan, many sexually active subjects used a condom. This compares with the 
results reported by Howard and McCable ${ }^{23}$ in the USA who found a significant increase in reported use of condom among sexually active high school students who were exposed to peerled intervention. Condoms protect users from pregnancy and STD and do not require medical supervision.

There are some implications on the design used in this study. Unlike previous studies, the design of this study provided opportunity for comparison of relative effects of interventions. Thus the study shows that although any intervention is better than nothing, some are more superior to others. The mixed intervention produced a synergy in which teachers and students peer educators reinforced the effects of each other. Two, contrary to the experience reported by other investigators in which secondary school teachers often expressed reluctance on how to implement what they have been trained to present because of lack of encouragement ${ }^{24}$ there was a sense of partnership for reproductive health education developed at the $\mathrm{E} 3$ with both teachers and peer educators challenging each other to keep up their roles in the educational process.

\section{Conclusion}

Teachers and students can be successfully used as change agents in the school environment if given adequate training. ${ }^{25}$ The human resources required to implement reproductive health project exist in most secondary schools in Nigeria including those found in rural areas with weak economic and social infrastructures. Despite their potential as effective sources of reproductive health education, secondary schools remain under utilized for reproductive health education activities in Nigeria. However, this situation must change in the light of growing research evidence that schools can make a difference in the reproductive health of adolescents. If provided with adequate training and supportive supervision, students and teachers can implement good quality program in schools. The intervention with the greatest potential of success in a school environment is one in which teachers and students play complimentary roles. It reinforces the fact that multiple interventions used together can enhance the effectiveness of a project.

\section{REFERENCES}

1. Makinwa-Adebusoye, P Sexual behavior, reproductive knowledge and contraceptive use among young urban Nigerians. Inter Fam Plan Pers 1993; 18, 66-70

2. National Population Commission (2007). 2006 Provisional Census figures

3. Jinadu, MK, Odesanmi, WO. Adolescent sexual behavior and condom use in Ile-Ife, Nigeria. Clin Nurs Res, 1993; 3 (2): 111-118.

4. Amazigo U, Silva N, Kaufman J and Obikeze DS. Sexual activity and contraceptive knowledge and use among in-school adolescents in Nigeria. Inter Fam Plan Pers, 1998; 23(1): 28-33

5. Ajuwon AJ, McFarland W, Hudes ES, Adedapo S, Okikiolu T and Lurie P. HIV risk-related behavior, sexual coercion, and implications for prevention strategies among female apprentice tailors in Ibadan, Nigeria. AIDS and Behavior 2002; 6 (3): 229235

6. Ekweozor CC, Olaleye OD, Tomori O, Saliu I, Essien EM, Bakare RA, Oni AA, Oyewo OO, Okesola AO and Oyemenen IN. Clinical epidemiology of STD patients seen in Ibadan. Afr J. of Med Med Sci, 1995, 24: 321-7.

7 Federal Ministry of Health (2000). Summary of 1999 findings for HIV/syphilis surveillance, Lagos, Nigeria.

8. Fawole, OI (1996) The effectiveness of a school based AIDS/HIV education programme on the knowledge, attitude and sexual behavior of students in Ibadan North Local Government Area. FWACP dissertation, Faculty of Public Health, West African College of Physicians.

9. Osowole, OA (1998) Effectiveness of AIDS education using sign language among deaf secondary school students in Ibadan, Nigeria. PhD Thesis of the University of Ibadan.

10. Association for Reproductive and Family Health (1998) The West African Youth Initiative: African Journal of Reproductive Health Vol. 11 No.2 August 2007 
Promoting change in adolescent health through peer education

11. Oladepo $\mathrm{O}$ and Brieger WR (2003). Evaluation of a reproductive health program among out-ofschool youths in Oyo state, Nigeria. Unpublished Report of Rockefeller Foundation Project.

12. Oladepo O (1999). Use of male peer education to promote reproductive health of secondary school students in rural Oyo State, Nigeria. Report of a project on MacArthur Fund for Leadership Development

13. National Primary Health Development Agency. Federal Ministry of Health, Lagos, Nigeria

14. Ososanya, OO, Brieger, WR. Rural-urban mobility in southwestern Nigeria: implications for HIV/ AIDS transmission from urban to rural communities. Health Edu Res, 1994; 9 (4): 507-518

15. Olusanya PO. The barriers to family planning among the Yoruba. Stud Fam Plan, 1969; 37: 13-16

16. Brieger WR, Delano GE, Lane C, Oladepo O and Oyediran K. West African Youth Initiative: outcome of reproductive health education program. J Adoles, 2001; 29; 436-446

17. Coates T (1991). Principles of behaviour change. Network. Family Health International, 12 (1): 3-5,

18. Oladapo, O and Brieger, WR. Reproductive Knowledge, attitudes and behaviour of secondary school students in Akure, Nigeria. Int Quart Comm Health Edu, 1997;16 (4): 341-358
19. Rickert, VI, Jay, MS and Gottlieb A. Effects of a per-counselled AIDS education programme on knowledge, attitudes and satisfaction of adolescents. I Adoles Health 1991; 12 (1): 38-43

20. Akpan, E. The efficacy of peer education on knowledge and attitudes towards use of psychoactive substances among secondary school students in Igbo-ora, Nigeria. MPH dissertation of the University of Ibadan

21. Fishbein, $\mathrm{M}$ and Middlestadt.. Using the theory of reasoned action to develop educational interventions: applications to illicit drug use. Health Edu Res 1987; 2 (4): 361-372

22. Aral, SO (1992) Sexual behavior as a risk factor for sexually transmitted diseases. In: Reproductive tract infections: global impact and priorities for women's reproductive health (Ed) Germain K. K, Piot P and Wasserhelt Plenum press, New York, 185-198

23. Howard, M, McCable, JB. Helping teenagers postpone sexual involvement. Inter Fam Plan Pers 1992; 22: 21-26.

24. Brieger, WR, Ramakrishna, J, Adeniyi, JD and Lekwa, MU. Primary schools: making teaching relevant to local issues. Educ Health 1985; 2 (1): 39-46

25. Ekeh, HE (1987) intervening in social and behavioural dimensions of tropical diseases control among secondary schools children: An extra curricular approach. Ph. D. thesis of the University of Ibadan 